\title{
PENGARUH LATIHAN FISIK TERHADAP KEKUATAN OTOT PASIEN GAGAL GINJAL KRONIS DI RUANG HEMODIALISA
}

\author{
Fitri Rahayu \\ Dwi Wulandari \\ Dilfera Hermiati \\ (Fakultas Ilmu Kesehatan, Universitas Dehasen Bengkulu, Email: \\ fitri.raharsyah@gmail.com)
}

\begin{abstract}
ABSTRAK
Memperbaiki kapasitas kerja fisik dan mengurangi keterbatasan fungsi kekuatan otot dapat dilakukan melalui latihan fisik secara teratur pasien penyakit ginjal kronik setelah menjalani hemodialisis. Tujuan dalam penelitian ini untuk mengetahui Pengaruh pelaksanaan Latihan fisik terhadap peningkatan kekuatan otot pada pasien penyakit ginjal kronik di ruang Hemodialisa Rumah Sakit M. Yunus Bengkulu. desain dalam penelitian ini adalah analitik menggunakan rancangan Quasi Experimental Design (One Group Pre Tes-Post Test Design) yang dilakukan dengan memberikan pengamatan dan penilaian awal terlebih dahulu pada pasien sebelum diberikan intervensi penelitian berupa latihan fisik setelah pelaksanaan pengobatan hemodialisa, kemudian pasien diberikan intervensi berupa Latihan Fisik pada pasien menggunakan alat Dumbbell dan ankle kuff pada ekstremitas, kemudian dilakukan pengamatan terakhir dengan mengukur kekuatan otot pasien. Jumlah responden 30 orang pasien. Hasil analisis menggunakan uji pairetd $T$ test diperoleh rata-rata (mean) pretest yaitu 0,70 dan nilai posttest yaitu 0,47 dengan nilai signifikansi sebesar 0.006 yang berarti terdapat pengaruh yang bermakna pengaruh latihan fisik terhadap kekuatan otot pasien gagal ginjal kronik di ruang hemodialisa Rumah Sakit M. Yunus Bengkulu. Latihan fisik dapat digunakan menjadi salah satu intervensi dalam asuhan keperawatan post hemodialisa diruangan, sehingga dapat mengurangi efek yang terjadi post hemodialisa seperti keram pada bagian tubuh yang dilakukan pemasangan Intravena, dan mengurangi gangguan kekuatan otot akibat tirah baring yang lama selama menjalani hemodialisa.
\end{abstract}

Kata Kunci: Latihan Fisik, Kekuatan Otot

\section{ABSTRACT}

Physical exercise is one way to improve physical work capacity and reduce the limitations of function but it is not yet known how the effectiveness of physical exercise performed on the muscle strength of patients with chronic kidney disease after undergoing hemodialysis. This study aims to determine the effect of physical exercise on increasing muscle strength in patients with chronic kidney disease in the hemodialysis room in M.Yunus Hospital. The type of this research is analytic research with the design of Quasi Experimental Design (One Pre Pre Test-Post Test Design), ie a study is conducted by giving initial observations before being given an intervention, after which the intervention is given, then the last 
observation is carried out. With the number of respondents 30 people. Based on the results of the analysis with the pairt $t$ test, the mean score (average) of the pretest value is 0.70 and the posttest value is 0.47 with a significance value of 0.006. Therefore $(p<0.05)$ then there is a significant effect of the effect of physical exercise on the muscle strength of patients with chronic renal failure in the hemodialysis hospital. For the nursing profession, physical exercise can also be an intervention in post hemodialysis nursing care in the room, so that it can reduce the effects of post-hemodialysis such as cramps on the body parts that are done intravenously, and reduce muscle strength due to prolonged bed rest during hemodialysis.

Keywords: Physical Exercise and Muscle Strength

\section{PENDAHULUAN}

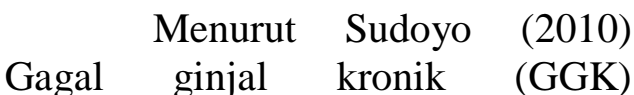
merupakan kejadian patofisiologis pada ginjal dengan etiologi yang beragam, sehingga mengakibatkan terjadinya penurunan fungsi ginjal yang irreversibel dan progresif dimana tubuh mengalami kegagalan dalam mempertahankan metabolisme serta keseimbangan cairan dan elektrolit yang menyebabkan kondisi uremia pada pasien.

Penelitian yang dilakukan firmansyah 2014 setiap tahunnya, angka kejadian gagal ginjal kronik ini meningkat. Data Pasien penyakit ginjal kronik di seluruh dunia pada tahun 2010 sampai dengan 2013 mengalami peningkatan sebanyak satu juta orang yang menjalani terapi penggantian ginjal (Hidayti, 2013).

Insiden GGK di negara maju cukup tinggi dan meningkat setiap tahunnya. Di negara Amerika Serikat pada tahun 2014 jumlah penderita GGK mencapai 1,752 per juta penduduk, meningkat $1 \%$ dari tahun 2013. Ada 50.000 orang Amerika meninggal akibat penyakit gagal ginjal kronis yang menetap setiap tahunnya. Sebanyak 593.992 populasi yang menjalani pengobatan dimana $65 \%$ pasien menjalani terapi hemodialisa, $5 \%$ pasien menjalani dialysis peritonical dan $30 \%$ pasien dengan transpalantasi ginjal (United States Renal Data System, 2014). Berdasarkan estimasi World Health Organization (WHO) pasien GGK harus menjalani hidup bergantung pada hemodialisa sekitar 1,5 juta orang.

Riset Kesehatan Dasar (RISKESDAS) pada tahun 2015 GGK merupakan salah satu penyakit yang termasuk kedalam 10 besar penyakit kronis di Indonesia. Penyakit GGK di Indonesia mencapai 30,7 Juta penduduk. Dengan data penatalaksanaan yaitu sebesar $82 \%$ dengan hemodialisa, sebesar 2,6\% dengan transpalantasi ginjal, 12,8 \% dengan Continous Ambulatory Peritoneal Dialysis (CAPD), dan 2,3 \% dengan Continuous Renal Replacement Therapies (CRRT).

Menurut data survey Persatuan Nefrologi Indonesia (PERNEFRI) berdasarkan laporan Indonesian Renal Registry (IRR) (2015), pasien aktif yang menjalani terapi hemodialisa terjadi peningkatan pada tahun 2015 yaitu tercatat dari 9396 orang pada tahun 2014 menjadi 11689 orang dan untuk pasien baru yang menjalani hemodialisa pada tahun 2014 dari sebanyak 15128 orang meningkat 
menjadi 17193 orang pada tahun 2015 .

Provinsi Bengkulu

memiliki data pasien gagal ginjal yang cukup tinggi dari tahun ke tahun. pada tahun 2013 pasien aktif yang menjalani hemodialisa mencapai 1987 orang kemudian terjadi peningkatan sebesar 19161 orang pada tahun 2014 sedangkan berdasarkan data pasien baru yang terdiagnosa menjalani hemodialisa pada tahun 2013 yaitu berjumlah 2104 orang, meningkat pada tahun 2014 menjadi 2149 orang (IRR, 2014).

Data yang diperoleh dari Medical Record di seluruh rumah sakit yang berada di provinsi Bengkulu, tercatat pasien gagal ginjal kronis pada tahun 2014 berjumlah 1368. Jumlah data ini didapatkan dari rumah sakit yang mempunyai hemodialisis room, dimungkinkan angka kejadian pasien yang menderita gagal ginjal kronis jauh lebih banyak dari jumlah tersebut (Ayuandira, 2015).

Hemodialisa merupakan suatu proses bagi pasien yang mengalami gagal ginjal tahap akhir (stage V) dan pasien yang memerlukan terapi dialisis jangka pendek yang bertujuan untuk pengeluaran sisa hasil metabolisme dan kelebihan cairan serta zat-zat yang tidak dibutuhkan oleh tubuh. Hemodialisa merupakan pengganti fungsi ginjal dilakukan seumur hidup pada pasien gagal ginjal kronik. Terapi hemodialisa bertujuan untuk mempertahankan kehidupan dan kualitas hidup pasien sampai fungsi ginjal pulih kembali, namun bukan untuk menyembuhkan (Fransisika, 2012).

Terapi penggantian fungsi ginjal adalah salah satu terapi yang bisa diberikan pada pasien yang mengalami penyakit gagal ginjal kronik tahap akhir. Tindakan dialisis merupakan suatu proses yang dapat digunakan pada pasien dengan kondisi penyakit akut maupun kronis yang memerlukan terapi dialisis jangka pendek maupun permanen sesuai dengan kondisi pasien (Muniralanam, 2015).

Terapi hemodialisis dapat mencegah kematian maupun memperpanjang usia pasien GGK pada stadium terminal. Diketahui bahwa terapi hemodialisis tidak dapat menyembuhkan atau memulihkan penyakit ginjal, pasien akan tetap mengalami sejumlah manifestasi klinis maupun komplikasi akibat perubahan pada bentuk dan fungsi sistem dalam tubuh akibat kerusakan Ginjal (Hidayti, 2013).

Hasil penelitian firmansyah 2014 menyatakan Pelaksanaan latihan fisik setelah menjalani terapi hemodialisis dapat Peningkatan Kekuatan Otot pada ekstremitas Pasien Gagal Ginjal Kronik di Rumah Sakit Umum Daerah Kota Semarang. Permasalahan yang sering dikeluhkan pada pasien post hemodialisis rutin adalah terjadinya kelemahan dan kekakuan otot pasca hemodialisa yang disebabkan karena bedres lama selama proses hemodialisis. Secara teori kelemahan otot tersebut disebabkan karena adanya pembatasan aktivitas selama hemodialisa, miopati otot, atrofi otot, neuropati atau kombinasi diantara keduanya (Firmansyah, 2014).

Sistem organisasi tingkat tinggi dari material organik yang menggunakan energi kimia untuk menghasilkan kerja mekanik dibawah kontrol sistem persyarafan disebut dengan otot. Otot yang 
mengalami kelemahan dapat diatasi dengan melakukan latihan fisik. Latihan fisik merupakan pergerakan terencana, teratur, terstruktur dan terarah yang dilakukan untuk memperbaiki dan memelihara satu atau lebih aspek kebugaran fisik pada seseorang yang mengalami kelemahan otot (Kadir, 2013).

Latihan fisik bertujuan

untuk mempertahankan dan meningkatkan kesehatan tubuh secara keseluruhan serta melancarkan sistem peredaran darah. Ada tiga metode latihan fisik secara umum dapat dilakukan pada pasien dengan penyakit ginjal tahap akhir yaitu program latihan selama 60 menit pertama saat dilakukan hemodialisis di unit hemodialisis program latihan di pusat rehabilitasi dengan supervisi, program rehabilitasi latihan di rumah (Knap, 2015).

Latihan fisik yang dilakukan selama proses dialisis dapat meningkatkan aliran darah pada otot dan memperbesar jumlah kapiler serta memperbesar luas permukaan kapiler sehingga meningkatkan perpindahan toksin dan urea dari jaringan ke vaskuler kemudian dialirkan ke dializer atau mesin hemodialisis. Latihan fisik dilakukan setelah pasien menjalani proses hemodialisis (Muniralanam, 2015).

Pelaksanaan latihan fisik bisa menurunkan skala kekakuan otot maupun kelemaha otot setelah melaksanakan hemodialisa. Salah satu jenis latihan fisik yang dapat dilakukan post hemodialisis adalah latihan kekuatan otot dengan menggunakan alat. Otot akan menjadi kuat dan bekerja lebih keras jika dilakukan latihan kekuatan otot secara continue, dengan melawan gaya resistensi. Kekuatan otot dibutuhkan sebagai dasar untuk melakukan aktifitas fisik lain. Selain itu kekuatan otot dapat memperlancar peredaran darah setelah hemodialisa dan memberikan pergerakan dar relaksasi setelah berbaring lama menjalani hemodialisa. Penelitian yang dilakukan delima, (2013) melaporkan dalam penelitiannya, stregh thening exercise dapat meningkatkan kekuatan otot pernapasan, kapasitas fungsional, dan kualitas hidup pada pasien GGK yang menjalani hemodialisis.

Hasil penelitian Johansen (2011) menyarankan pada tenaga kesehatan khusunya perawat untuk melaksanakan latihan kekuatan (strength traning) pada pasien post hemodialisi menjadi aktifitas rutin dari perawatan terapi pasca hemodialisis untuk meningkatkan kualitas hidup pasien dialysis setelah menjalani terapi, sekaligus meningkatkan kekuatan otot pasien.

$$
\text { Pelaksanaan latihan }
$$

kekuatan pada ekstremitas bawah dapat membantu mengurangi gejala kelemahan dan kekakuan post hemodialisa. Latihan ini efektif dilakukan selama 30 sampai dengan 45 menit dan secara umum diberikan post hemodialisis. Latihan dilakukan sebanyak 2 set, satu set latihan terdiri dari 8 kali untuk kelompok otot besar ekstremitas atas dan bawah dengan tujuan untuk meningkatkan kekuatan otot. Sedangkan set berikutnya dilakukan pada ekstremitas bawah (Agency of Healthcare Research and Quality, 2010).

Berdasarkan penelitian yang dilakukan Knap (2015) penatalaksanaan latihan fisik setelah hemodialisis dapat meningkatkan VO2 peak, serta menurunkan self- 
reported depression pada otot ekstremitas atas dan bawah, serta menunjukkan perkembangan yang signifikan pada quality of life index dan life satisfaction index pasien post hemodialisa. Pelaksanaan latihan fisik post hemodialisis dapat menjaga stabilitas tekanan darah sistolik dan diastolik pada pasien (Hidayati, 2013).

$$
\text { Hasil penelitian yang }
$$

dilakukan Sulisyaningsih, 2016 tentang pengaruh latihan fisik setelah hemodialisis terhadap 21 Responden bisa mengurangi ansietas (kecemasan), sehingga menunjukkan kecenderungan perbaikan pada level of aerobic fitness. Kejadian atrofi otot pada ekstremitas atas maupun bawah dapat diatasi secara bertahap dengan pelaksanaan latihan ketahanan secara signifikan dan teratur, sehingga dapat meningkatkan kekuatan otot dan ukuran miofiber pada pasien dengan kegagalan ginjal kronis (Sulisyaningsih, 2016).

$$
\text { Keterbatasan dalam }
$$

melakukan aktivitas dapat menyebabkan penurunan kekuatan otot dan mengakibatkan atrofi pada otot baik ekstremitas atas maupun bawah. Aktivitas yang biasa dilakukan pasien selama proses hemodialisis adalah berbincangbincang dengan keluarga atau pasien yang lain, minum, makan dan tidur. Dengan latihan fisik dapat menjadikan salah satu alternatif dalam memperbaiki kapasitas kerja fisik dan mengurangi keterbatasan fungsi. akan tetapi belum diketahui secara pasti bagaimana efektivitas latihan fisik yang dilakukan terhadap kekuatan otot pasien penyakit gagal ginjal kronik setelah menjalani terapi hemodialisis.

Berdasarkan data yang diperoleh dari Kota Bengkulu angka kejadian GGK yang mendapatkan terapi hemodialisa pada tahun 2016 sebanyak 678 kasus sedangkan pada tahun 2017 mengalami peningkatan sebanyak 765 kasus (Dinkes Kota Bengkulu, 2017). Data dari ruang hemodialisa RS M. Yunus angka kejadian GGK yang mendapatkan terapi hemodialisa sebnyak 567 kasus pada tahun 2016, dan pada tahun 2017 meningkat menjadi 668 pasien. Sementara data satu bulan terakhir yang didapatkan kunjungan pasien GGK yang melakukan terapi hemodialisa sejak 1 Januari s/d 31 Januari 2018 sebanyak 69 Orang (Data Ruang Hemodialisa RS M. Yunus, 2018).

Berdasarkan survey awal yang peneliti lakukan pada 6 orang pasien setelah menjalani hemodialisa didapatkan 4 orang pasien mengalami kelemahan dan kekakuan otot setelah menjalani terapi hemodialisa, sementara 2 orang pasien lagi mengeluh mengalami kram pada daerah tungkai yang dipasang cimino dan terasa nyeri serta kebas pada daerah ujung kaki.

\section{METODOLOGI PENELITIAN}

Jenis penelitian ini adalah
analitik dengan
menggunakan rancangan penelitian
Quasi Experimental Design (One
Group Pre Tes-Post Test Design)
yaitu merupakan suatu penelitian
yang dilakukan dengan cara
memberikan pengamatan awal
terlebih dahulu terhadap suatu objek
sebelum diberikan intervensi
(perlakuan), setelah itu responden
diberikan perlakuan (treatment),
kemudian dilakukan pengamatan
terakhir (Sulistyaningsih, 2012).
Tempat penelitian ini dilakukan di
ruangan Hemodialisa Rumah Sakit


M. Yunus Bengkulu. Populasi dalam penelitian ini adalah seluruh penderita penyakit Gagal ginjal Kronis yang mendapatkan terapi Hemodialisa dalam satu bulan terakhir sebanyak 69 Orang. Jumlah sampel dalam penelitian ini adalah sebanyak 30 sampel.

Cara pengambilan sampel dalam penelitian ini menggunakan tehnik Purposive Sampling yaitu merupakan salah satu teknik pengambilan sampling Non Random Sampling dimana peneliti menentukan pengambilan sampel dengan menetapkan ciri-ciri khusus yang sesuai dengan tujuan penelitian sehingga diharapkan dapat menjawab permasalahan penelitian. dengan Kriteria ekslusi sampel pasien mengalami penyakit pada sistem persyarafan, Pasien tidak mengalami komplikasi hemodialisa (hipotensi, sakit kepala, mual dan muntah serta mengeluh nyeri), Tidak mengalami gangguan hemodinamik, berikan persetujuan oleh dokter untuk melakukan latihan fisik setelah hemodialisa, Pasien Bersedia menjadi responden. Sedangkan kriteria ekslusi dalam penelitian ini adalah Pasien yang menunjukan tanda-tanda Syok. Analisa data yang digunakan dalam penelitian ini adalah Uji T. test.

\section{HASIL PENELITIAN}

Hasil Penelitian dapat dilihat pada tabel 1 dibawah ini:

Tabel. 1 gambaran Kekuatan Otot pada pasien sebelum dilakukan Latihan Fisik diruang Hemodialisa RS M. Yunus Kota Bengkulu.

\begin{tabular}{lccc}
\hline & Kekuatan otot & Frekuensi & Persentase $(\%)$ \\
\hline Maksimal & 9 & 30,0 \\
Minimal & 21 & 70,0 \\
\hline
\end{tabular}

Berdasarkan tabel di atas diketahui dari sebagian besar responden $\quad(70,0 \%)$ memiliki kekuatan otot minimal dengan beban
$<10 \mathrm{Kg}$, dan hampir sebagian responden $(30,0 \%)$ memiliki kekuatan otot beban maksimal dengan beban $>=10 \mathrm{Kg}$.

Tabel 2. Ginjal Kronik Sesudah dilakukan Latihan Fisik diruang Hemodialisa RS M. Yunus Bengkulu

\begin{tabular}{lccc}
\hline & Kekuatan otot & Frekuensi & Persentase (\%) \\
\hline Maksimal & 16 & 53,3 & \\
Minimal & 14 & 46,7 & 100 \\
\hline Jumlah & 30 & & \\
\hline
\end{tabular}

Berdasarkan tabel di atas diketahui sebagian besar responden $16(53,3 \%)$ memiliki kekuatan otot maksimal sesudah dilakukan latihan fisik dengan beban $>=10 \mathrm{Kg}$, sedangkan hampir sebagian 
responden $14 \quad(46,7 \%)$ memiliki kekuatan otot minimal sesudah dilakukan latihan fisik dengan beban $<10 \mathrm{Kg}$.

Tabel 3. Hasil Uji paired t test Pratest dan Posttest tentang pengaruh latihan fisik terhadap kekuatan otot pasien gagal ginjal kronis di ruang hemodialisa RS. M.Yunus Bengkulu

\begin{tabular}{cccc}
\hline Kelompok data & $\mathrm{N}$ & Mean & $p$ \\
\hline Pretest & 30 & 61 & 0.006 \\
Posttest & 30 & 75 & \\
\hline
\end{tabular}

Berdasarkan hasil analisis dengan menggunakan uji pairetd $t$ test didapatkan nilai mean (rata rata) dari nilai pretest yaitu 61 dan nilai posttest yaitu 75 dengan nilai signifikan sebesar 0.006 Oleh karena

\section{PEMBAHASAN}

Jaringan konektif di dalam
tubuh yang utamanya
menggunakan kontraksi disebut otot.
Kontraksi otot yang digunakan untuk
memindahkan bagian-bagian tubuh
dan substansi dalam tubuh. Jaringan
otot ini tersusun atas sel-sel otot yang
fungsinya melakukan pergerakan
pada organ-organ tubuh.
Kemampuan ini disebabkan karena jaringan otot mampu berkontraksi secara optimal. Kontraksi otot dapat berlangsung jika molekul-molekul protein yang membangun sel otot dapat memanjang dan memendek secara normal. Otot memiliki peranan penting sebagai penghasil energi bagi tubuh. Semakin bertambah massa otot, energi yang dihabiskan semakin bertambah, begitu juga sebaliknya yang akan membantu dalam mengurangi kadar lemak tubuh dan menurunkan berat badan dengan cara yang sehat (Muniralanam, 2015).
( $\mathrm{p}<0.05)$ maka terdapat pengaruh yang bermakna antara latihan fisik terhadap kekuatan otot pada pasien gagal ginjal kronik di ruang hemodialisa RS. M. Yunus Bengkulu.
Kekuatan atau (Strength) adalah ketahanan maksimal yang dapat dihasilkan selama kontraksi otot dalam kecepatan kontraksi tertentu (Robergs dan Keteyian, 2003). Kekuatan otot sebagai ketahanan maksimum yang dapat dihasilkan oleh sebuah otot atau kumpulan otot (Kadir, 2013).

Tingkat kekuatan otot yang dimiliki oleh manusia satu dengan yang lain tidak selalu sama hal ini disebabkan karena energi yang dimiliki tiap orang berbeda. Beberapa faktor yang mempengaruhi tingkat kekuatan otot ini adalah sebagai berikut makanan, dan gizi makanan. Kondisi gizi ini sangat berpengaruh bagi tubuh manusia, karena makanan yang masuk ke dalam tubuh akan diproses dan menghasilkan kalori sebagai sumber tenaga dan zat pembangun yang sangat diperlukan oleh tubuh sehingga tubuh dapat melakukan aktifitas secara maksimal. Tubuh 
membutuhkan panas untuk menjaga kondisi supaya stabil dalam menyesuaikan dengan lingkungan.begitu juga di dalam melaksanankan aktivitas sehari-hari, tubuh memerlukan kalori sebagai sumber tenaga, yang diperoleh dari makanan yang dimakan seseorang serta nilai yang gizi yang ada di dalam tubuhnya. Makin baik makan yang dikonsumsi yang mengandung 4 sehat 5 sempurna, maka makin baik pula kondisi tubuhnya serta energi yang dihasilkan. Sedangkan makanan yang mengandung 4 (empat) sehat 5 (lima) sempurna adalah makanan pokok (nasi, jagung, gandum), lauk pauk, sayuran, susu dan buah-buahan.

Faktor Istirahat dan tidur setelah melakukan aktivitasnya sehari-hari tubuh merasa letih, dan lelah. Untuk mengembalikan tenaga yang telah dipakai, diperlukan istirahat. Dengan beristirahat tubuh akan menyusun kembali tenaga yang hilang agar dapat digunakan dalam aktivitas yang lain. Istirahat penting dalam proses pengembalian tenaga, diperlukan pegaturan antara istirahat dan aktivitas yang dilakukan. Kondisi istirahat yang paling ideal dan paling baik adalah tidur. Secara alamiah tubuh memerlukan tidur dan beristirahat sesudah bekerja keras dan beraktifitas (Ardianto, 2013).

Faktor latihan dan olahraga secara teratur dapat mneingkatan kebugaran jasmani, sehingga dapat meningkatkan pula potensi dan prestasi kerja seseorang. Hal ini seperti hasil penelitian dikemukakan oleh Matias bahwa latihan gerak badan atau berolahraga yang terstruktur yang terdiri dari pemanasan, gerakan inti sampai dengan pendinginan merupakan rangsangan bagi pertumbuhan, sehingga badan dapat berkembang dengan baik dalam batas potensi. Olahraga dapat dilakukan sebagai reaksi diantara kegiatan jam-jam belajar atau jam-jam kerja, sehingga tidak saja merupakan usaha pemeliharaan kondisi fisik, akan tetapi juga menyegarkan kembali perasaan yang menjemukan karena kesulitan di dalam masalah belajar ataupun bekerja.

Review dosis pemberian latihan fisik bagi pasien gagal ginjal kronis yaitu 3 kali dalam seminggu. Dosis hemodialisis yang diberikan di Indonesia umumnya 2 kali seminggu. Smart dan Stelee (2013) merekomendasikan latihan fisik dalam jangka waktu lama yaitu 5 bulan baru dapat memberikan efek yang menguntungkan. Pedersen dan Saltin (2006) melakukan review dosis latihan fisik pada penyait kronis. Gagal ginjal kronis yang memiliki karekteristik pasien hampir sama dengan pasien gagal jantung kronik, akan didapatkan efek positif pada pasien jika melakukan latihan kekuatan selama 10 minggu sampai 5 bulan.

Berdasarkan hasil analisis dengan uji pairetd $t$ test didapatkan nilai mean (rata - rata) dari nilai pretest yaitu 0,70 dan nilai posttest yaitu 0,47 dengan nilai signifikansi sebesar 0.006 Oleh karena $(\mathrm{p}<0.05)$ maka terdapat pengaruh yang bermakna pengaruh latihan fisik terhadap kekuatan otot pasien gagal ginjal kronik di ruang hemodialisa RS. M. Yunus Bengkulu.

Kelemaha dan kekakuan akibat berbaring lama saat menjalani hemodialisa dapat menyebabkan keletihan, kelemahan serta kekakuan otot pasien, karena berbaring dalam waktu cukup lama tanpa ada pergerakan, dengan dilakukannya 
latihan fisik ini akan memperbaiki peredaran darah dan mengurangi kelemahan pada tubuh pasien. Penelitian yang dilakukan de-Lima et al. (2013) pun memberikan efek positif terhadap kekuatan otot. Kekuatan otot responden setelah perlakuan tidak diobservasi oleh peneliti, namun berdasarkan studi literatur bahwa kekuatan otot yang meningkat berpotensi memperbaiki kondisi karena dengan peningkatan kekuatan otot akan berpengaruh terhadap kestabilan kontrol motor (Griffin \& Cafarelli, 2005). Sehingga berdasarkan hasil penelitian tersebut, peneliti mengambil gerakan minimal dalam prosedur latihan kekuatan namun tetap memberikan pengaruh terhadap penelitian ini. Durasi atau lamanya pemberian intervensi, menentukan keoptimalan

Latihan fisik selama hemodialisa belum banyakditerapkan di unit hemodialisa sebagai intervensi pada pasien post pelaksanan hemodialisa, meskipun manfaat latihan fisik ini sangat besar dalam mengurangi gangguan peredaran darah selama bedres dalam menjalani hemodialiasa (Nasution, 2010). (2015) mengungkapkan bahwa latihan fisik post hemodialisa dapat memperbaiki peredaran darah akibad bedres dalam beberapa jam menjalani hemodialisa, sehingga akan mengurangi rasa keram akibad duduk atau bedres lama, di daerah insersi post hemodialisa, selain itu memberikan kebugaran pada pasien, dan mengurangi rasa nyeri yang merupakan efek hemodialisa, latihan fisik akan merelaksasi otot-otot sehingga akan merasa lebih nyaman dan jalanya peredaran darah menjadi lebih optimal.

\section{SIMPULAN}

1. Sebagian besar responden memiliki kekuatan otot minimal dengan beban $<10 \mathrm{Kg}$ sebelum melakukan latihan fisik.

2. Sebagian besar responden memiliki kekuatan otot Minimal beban $>=10 \quad \mathrm{~kg}$ " sesudah melakukan latihan fisik

3. Ada pengaruh antara latihan fisik terhadap kekuatan otot pasien gagal ginjal kronik di ruang hemodialisa Rumah sakit M. Yunus Bengkulu sebelum dan sesudah dilakukan test.

\section{SARAN}

Hasil penelitian ini dapat memberikan gambaran Bagi profesi keperawatan, latihan fisik juga dapat menjadi intervensi dalam asuhan keperawatan post hemodialisa diruangan, sehingga dapat mengurangi efek yang terjadi post hemodialisa seperti keram pada bagian tubuh yang dilakukan pemasangan Intravena, dan mengurangi gangguan kekuatan otot akibat tirah baring yang lama selama menjalani hemodialisa.

Dari hasil penelitian ini, penelitian selanjutnya dapat meneliti latihan fisik dengan mengembangkan konsep penelitian seperti pengembangan variabel yang diujikan, contohnya pemeriksaan kualitas tidur, stres/depresi atau meluaskan area penelitian serta menambah frekuensi pemberian Latihan fisik agar bisa melihat efek- 
efek lain yang ditimbulkan dari penerapan latihan fisik. Pengembangan penelitian ini dapat menjadi bahan analisa yang lebih mendalam. Bagi pasien yang

\section{DAFTAR PUSTAKA}

Ambarwati, N.M.R. 2015. Pengaruh Latihan Circuit Training Dan Cross Country Terhadap VO2max. Skripsi. Bandar Lampung: Universitas Lampung.

Ardianto, S., Imas D., Nur I.R. 2013. Hubungan Antara Antropometri Tubuh Dengan Kelincahan (Agility) Dan Daya Tahan Kardiovaskular (VO2max) Pada Olahraga Basket. Bandung: IKOR ,Volume 1 Nomor 3, Desember 2017.

Aru Sudoyo. (2010). Ilmu penyakit dalam jilid IV edisi I. Pusat penerbitan departemen ilmu penyakit dalam FKUI : Jakarta

Ayu. (2012). Hubungan antara quick of blood dengan adekuasi hemodialisa pada pasien HD. Bali. Tidak dipublikasikan.

Cahyaningsih, Niken D. (2011). Hemodialisa: Panduan Praktis Perawatan gagal Ginjal. Jogjakarta: Mitra Cendekia Press.

Cahyanto, A. 2014. Pengaruh Circuit Training Terhadap Peningkatan Kebugaran Jasmani Dan VO2Max Dalam Permainan Sepakbola. Lampung: Universitas Lampung ( Diakses: 03 Desember 2017). terdiagnosa gagal ginjal kronis yang dapat melakukan latihan fisik setelah melakukan hemodialisa dengan baik dan tidak tirah baring setelah melakukan terapi hemodialisa.

Data Ruang Jemodialisa RS Sobirin. 2018. Data hemodialisis pasien GGK RS Dr. Sobirin. Musirawas. Kota lubuklinggau.

de-Lima, M.C., Cicotoste, C., Cardoso, K.D., Junior, L.G.F., Monteiro, M.B., \& Dias AS. (2013). Effect of exercise performed during hemodialysis: Strength versus Aerobic. Renal Failure

Echder T, Schriner RW. 2012. Cardiovascular

Abnormalites in Autosomal Dominant Polistic Kidney Disease. Nat Rev Nephrol.

Firmansyah, A.M. (2014). Usaha memperlambat perburukan penyakit ginjal kronik ke penyakit ginjal stadium akhir. Cermin Dunia Kedokteran; ISSN: 0125913 X/ 176 / vol. 37 no. 3/ April 2014.

Fransiska, Kristina. 2012. 24 Penyebab Ginjal Rusak. Jakarta : Penerbit Cerdas Sehat.

Hidayati. W. (2013). Laporan analisis praktek residensi spesialis keperawatan medikal bedah peminatan sistem perkemihan di RSUPN dr. Cipto Mangunkusumo dan RS PGI Cikini, tidak dipublikasikan.

Hidayati, Sri (2012). Tesis: Efektifitas Konseling 
Analisis Transaksional

Tentang Diet Cairan

Terhadap Penurunan

Interdialytic Weight Gain

(IDWG) Pasien Gagal

Ginjal Kronik Yang

Menjalani Hemodialisa Di

Rumah Sakit Umum Daerah

Kardinah Tegal.

Huddak \& gallo. (2010).

Keperawatan kritis:

Pendekatan Holistik.

Jakarta: EGC

Kadir, A. 2013. Adaptasi

Kardiovascular Terhadap

Latihan Fisik. Surabaya:

Universitas Wijaya Kusuma

Knap B, Ponikvar B.J, Ponikvar R,

Bren F.A. (2015). Regular exercise as a part of treatment for patients with end stage renal disease. Therapeutic Apheresis and Dialysis; 9 (3):211-213, Diunduh tanggal 29 Desember 2017, dari http://www.proquest.umi.co $\underline{\mathrm{m}}$

PERNEFRI.

(2015). Naskah

Lengkap Workshop Dan

Simposium Nasional

Peningkatan Pelayanan

Hemodialisis, Penyakit

Ginjal Dan Aplikasi

Indonesian Renal Registry.

Jakarta

Proseding PPNI. 2014 Dialysis; 9 (3):211-213, diperoleh dari http://www.Proquesumi.pq dauto tanggal 29 Juni 2010 Kusmana. D (2007). Olah raga untuk orang sehat dan penderita penyakit jantung. FKUI: Jakarta

Muniralanam. (2015). Hubungan antara kelemahan otot dan status albumin pada penderita gagal ginjal kronik dengan hemodialisis rutin. Tinjauan pustaka dan hasil penelitian UGM tidak dipublikasikan diperoleh melalui http://arc.ugm.ac.id diakses tanggal 27 September 2017.

Notoatmodjo, S. (2010). Metode Penelitian Kesehatan. Jakarta: Rineka Cipta

Nursalam. (2007). Konsep dan penerapan metodologi penelitian ilmu keperawatan. Jakarta: Salemba Medika

RIKESDAS. 2015. Laporan Hasil Riset Kesehatan Dasar (Riskesdas) Indonesia. Jakarta

Sulaiman. 2015. Penilaian antara Kualitas Hidup dan Stres pada Pasien Hemodialisa (online),

(http://www.usu.ac.id, diakses 19 November 2017).

Sulisyaningsih, R, D. (2016). Efektivitas latihan fisik selama hemodialisis terhadap peningkatan kekuatan otot pasien penyakit ginjal kronik di Rumah Sakit Umum Daerah Kota Semarang. Melalui ttps://www.google.co.id/sea rch?q= latihan+fisik+pasien. Diakses tanggal 10 Januari 2018.

Sulistyaningsih. 2012. Metode Penelitian Kebidanan Cetakan ke-2. Yogyakarta: Graha Ilmu

Sulistini, Rumentalia. (2014). Gambaran faktor yang berhubungan dengan fatigue padapasien yang menjalani hemodialisa di RSUP dr, Moh Husein Palembang. (tesis). Perpustakaan UI. 
Tambunan, Marihot (2011).

Komplikasi saat

Hemodialisa. RS. PGI

Cikini Jakarta

Wardani, Venny Kusuma. (2014). Hubungan Antara Asupan Energi Dan Protein Dengan Status Gizi (Sga) Pada Pasien Rawat Jalan Hemodialisis Di Yayasan Ginjal Diatrans Indonesia, Jakarta Timur Tahun 2014. Diunduh tanggal 12 Agustus 2014, dari www.academia.edu.
WHO. 2010. Pengertian Latihan Fisik.diakses tanggal 20Januari 2018. di unduh dari http:// repository. usu.ac.id/ bitstream/ $1234567 \quad 89 / 27$ 419 /4/ Chapter \%20II.pdf.

WHO. World Health Statistics 2015: World Health Organization; diakses tanggal 20 Jnauari 2018 dalam situs di unduh dari http:// repository. usu.ac.id/ bitstream/ $1234567 \quad 89 / 27$ 419 /4/ Chapter \%20II.pdf. 